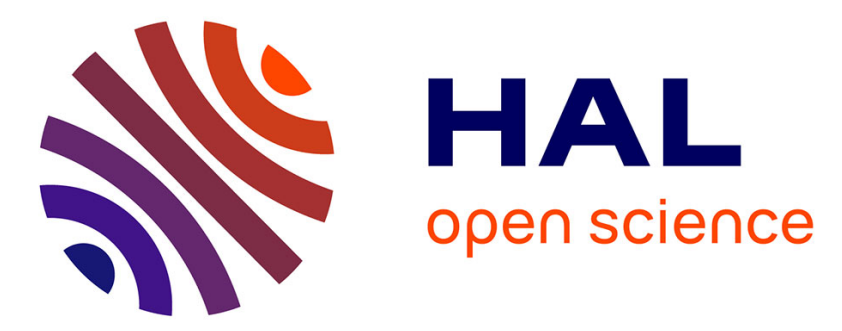

\title{
Progestogens and venous thromboembolism among postmenopausal women using hormone therapy.
}

Marianne Canonico, Geneviève Plu-Bureau, Pierre-Yves Scarabin

\section{To cite this version:}

Marianne Canonico, Geneviève Plu-Bureau, Pierre-Yves Scarabin. Progestogens and venous thromboembolism among postmenopausal women using hormone therapy.. Maturitas, 2011, 70 (4), pp.35460. 10.1016/j.maturitas.2011.10.002 . inserm-01148705

\section{HAL Id: inserm-01148705 https://www.hal.inserm.fr/inserm-01148705}

Submitted on 5 May 2015

HAL is a multi-disciplinary open access archive for the deposit and dissemination of scientific research documents, whether they are published or not. The documents may come from teaching and research institutions in France or abroad, or from public or private research centers.
L'archive ouverte pluridisciplinaire HAL, est destinée au dépôt et à la diffusion de documents scientifiques de niveau recherche, publiés ou non, émanant des établissements d'enseignement et de recherche français ou étrangers, des laboratoires publics ou privés. 
Progestogens and venous thromboembolism among postmenopausal women using hormone therapy

Marianne Canonico ${ }^{1,2}$, Geneviève Plu-Bureau ${ }^{1,3}$ and Pierre-Yves Scarabin ${ }^{1,2}$

${ }^{1}$ Centre for Research in Epidemiology and Population Health, U1018, Hormones and Cardiovascular Disease

2 University Paris-Sud, UMR-S 1018, Villejuif, France

${ }^{3}$ University Paris Descartes and Hôtel-Dieu Hospital, Paris, France

Adresse: $\quad 16$ av. Paul Vaillant Couturier 94807 Villejuif Cedex

Tel: $\quad$ +33145595166

Fax: $\quad+33145595170$

Corresponding author: Marianne Canonico (marianne.canonico@inserm.fr) 


\section{Abstract}

Hormone therapy $(\mathrm{HT})$ is the most effective treatment for correcting menopausal symptoms after menopause. HT initially consisted of estrogens alone and progestogens were secondly added to estrogens for preventing the risk of endometrial cancer associated to estrogens use. Venous thromboembolism (VTE), including deep vein thrombosis and pulmonary embolism, is a major harmful effect of $\mathrm{HT}$. It is now well known that oral and transdermal estrogens are differentially associated with VTE risk but progestogens may be another important determinant of the thrombotic risk among $\mathrm{HT}$ users. Both randomized controlled trials and metaanalysis of observational studies suggested that the VTE risk was higher among users of estrogens plus progestogens than among users of estrogens alone. With respect to the different pharmacological classes of progestogens, there is evidence for a deleterious effect of medroxyprogesterone acetate on VTE risk. In addition, observational studies showed that norpregnane derivatives were significantly associated with an increased VTE risk whereas micronized progesterone could be safe with respect to thrombotic risk. The effect of tibolone on VTE risk remains uncertain. In conclusion, progestogens may have differential effects on VTE risk according to the molecules and therefore represent an important potential determinant of the thrombotic risk among postmenopausal women using estrogens. 


\section{Introduction}

After menopause, many women suffer from postmenopausal symptoms associated with the decline of endogenous estrogens levels due to the cessation of ovary activity. Postmenopausal hormone therapy (HT) has been introduced in the 50' for correcting climacteric symptoms, vaginal dryness and depression. Initially, HT exclusively consisted of an estrogenic compound and in 70', progestogens were added to estrogens to reduce the increased risk of endometrial hyperplasia and cancer associated with estrogens therapy (ET) [1]. Currently, women may be prescribed several molecules including natural progesterone and synthetic compounds which have very different pharmacological effects.

Venous thromboembolism (VTE), either deep vein thrombosis or pulmonary embolism, is a main harmful effect of HT among postmenopausal women [2-4]. For about 10 years, epidemiological data have shown a differential association of oral and transdermal estrogens with the VTE risk among postmenopausal women [5-8]. Indeed, oral estrogens increase the VTE risk while transdermal estrogens appear to be safe with respect to thrombotic risk [4, 9]. More recently, the type of progestogens has also emerged as another important determinant of the thrombotic risk among $\mathrm{HT}$ users [6, 7, 9-11].

This review focuses on the different progestogens pharmacological classes in relation to VTE risk among postmenopausal women, including the current knowledge regarding the effect of progestogens on relevant haemostatic variables (prothrombin fragment $1+2(\mathrm{~F} 1+2)$ and Ddimers) as well as on activated protein $\mathrm{C}$ resistance (APCr), a validated surrogate marker of VTE. 


\section{Different pharmacological classes of progestogens}

Progestogens include both progesterone, the physiological molecule synthesized and secreted by ovary, and synthetic compounds named progestins which derived from either progesterone (pregnanes and 19-norpregnanes) or testosterone (19nortestosterone) [1]. Pregnanes derivatives consist of several molecules including dydrogesterone, medrogestone, chlormadinone acetate, cyproterone acetate and medroxyprogesterone acetate (MPA). Norpregnane derivatives include nomegestrol acetate, promegestone, trimegestone and nestorone. Finally, nortestosterone derivatives consist of ethinylated derivatives, non ethinylated derivatives, spironolactone derivatives and tibolone. Nortestosterone ethinylated derivatives are composed of estranes, including especially norethisterone acetate (NETA) and of gonanes which are preferentially used in contraceptive pills [1]. Nortestosterone non ethinylated derivative is dienogest and the spironolactone derivative is drospirenone. In European countries and especially in France, women are prescribed a wide variety of progestogens while MPA and some specific testosterone derivatives are the almost exclusive progestogens used in Anglo-Saxon countries [12].

Progestins have different pharmacological properties depending upon the parent molecules which they are derived and the metabolites they product (especially for nortestosterone derivatives). In addition, changes in progestogen effect occur according to the administered daily dose. Very small structural changes may induce considerable differences in the progestin activity (Table 1 ). The effects of progestins are related to interactions with the progesterone receptors but also with other steroid hormone receptors such as estrogens receptors, androgens receptors, glucocorticoid and mineralocorticoid receptors [13, 14]. These interactions may either induce or prevent the transactivation of steroid receptors. Therefore, the balance between the receptor coactivators and corepressors recruited by a progestin determines whether the overall effect of a molecule will be agonistic or antagonistic for each hormonal effect [15]. For example, some of progestins have a high antiandronegic activity and others possess progestogenic effect with antiestrogenic actions. 


\section{Progestogens and venous thromboembolism: clinical data}

\section{Estrogens alone versus Estrogens plus progestogens}

Since 1996, several observational studies have separately assessed the impact of unopposed estrogens and estrogen-progestogen therapy (EPT) on VTE risk among postmenopausal women. In these analyses, women used oral estrogens and no distinction was made between the different types of progestogens [5, 8, 16-19]. Using a random-effect model meta-analysis as previously described [4, 9], the overall VTE risk was 1.7 (95\% Confidence Interval (Cl):1.3-2.2) for ET use and 2.3 (95\%Cl: 1.73.2) for EPT use (figure 1). Despites a non significant difference between these two overall risk ratios $(p=0.15)$, this result showed that the VTE risk would be more elevated among EPT users as compared to ET users, suggesting a thrombogenic tendency of progestogens when associated to estrogens. However, no attempt was made in these studies to distinguish whether the different progestogens had the same influence on VTE risk.

\section{Different types of progestogens}

For many years, the association of VTE risk with the different pharmacological classes of progestogens has not been a mainstream topic for clinical investigations. Analysis of two randomized controlled trials allowed assessing the effect of MPA on VTE risk. On one hand, an indirect comparison of the Women's Health Initiative (WHI) clinical trials showed that the association of estrogens plus progestogens was more thrombogenic than unopposed estrogens [10, 20]. Indeed, compared to placebo, the VTE risk was 2.09 (95\% Cl: 1.59-2.74) and 1.34 (95\% Cl: 1.01-1.77) among HT users in the Estrogen plus Progestogen clinical trial and in the Estrogen alone clinical trial, respectively and this difference in VTE risk was statistically significant (CEE/CEE+MPA: 0.59; 95\%Cl: 0.37-0.94; $p=0.03$ ) [10]. On the other hand, the Women's International Study of long Duration Oestrogen after Menopause (WISDOM) trial has recently provided a direct comparison of the effect of conjugated equine estrogens (CEE) alone and CEE plus MPA on VTE risk among postmenopausal hysterectomised women [11]. Results showed that users of CEE plus MPA had a higher thrombotic risk than did women treated by CEE alone but this 
difference in VTE risk did not reach the signification (Hazard ratio $=2.39,95 \% \mathrm{Cl}$ : 0.62 9.24, $\mathrm{p}=0.19$ ).

With regard to the other progestogens, the ESTHER (EStrogen and THromboEmbolism Risk) Study, a French case/control study of VTE among postmenopausal women, was the first to establish a differential association of VTE risk with the different progestogen subgroups irrespective of the route of estrogens administration [6]. Results showed that micronized progesterone and pregnane derivatives might be safe with respect to thrombotic risk $(\mathrm{OR}=0.7 ; 95 \% \mathrm{Cl}: 0.3-1.9$ and $\mathrm{OR}=0.9 ; 95 \% \mathrm{Cl}: 0.4-2.3$, respectively) while norpregnane derivatives were associated with a significant increase in VTE risk (OR=3.9; $95 \% \mathrm{Cl}: 1.5-10.0)$. This study was the first to suggest that the type of progestogens could be a determinant of VTE risk as important as the route of estrogens administration among postmenopausal HT users. Few years later, the VTE risk by route of estrogens administration and type of progestogens among postmenopausal women has been further assessed in the E3N study (Etude Epidémiologique de l'Education Nationale), a large prospective French cohort study [7]. These results confirmed that the impact of progestogens on VTE risk was different according to the pharmacological classes. In this study, micronized progesterone was not associated with an increased VTE risk (OR=0.9; 95\%Cl: $0.6-1.5)$ while norpregnane derivatives could be thrombogenic (OR=1.8; 95\% $\mathrm{Cl}: 1.2-2.7)$. Nevertheless, uncertainty remained regarding the impact of pregnane and nortestosterone derivatives on VTE risk $(\mathrm{OR}=1.3 ; 95 \% \mathrm{Cl}$ : $0.9-2.0$ and $\mathrm{OR}=1.4 ; 95 \% \mathrm{Cl}: 0.7-2.4$, respectively), in part due to the lack of statistical power for subgroups analysis.

Despite their unquestionable interest, these results have to be cautiously interpreted since they have been obtained in observational studies which were subject to bias. In particular, a selection bias might have occurred due to the differential prescription of progestogens according to the estrogenic status of women using HT. Norpregnane derivatives are potent progestogens with antiestrogenic activity. Women with moderate to severe hyperestrogenic symptoms, such as breast tenderness or endometrial diseases, may be more likely to be prescribed these types of progestogens [21, 22]. Because there is evidence that lifetime estrogen exposure is positively related to VTE in postmenopausal women [23], this prescription bias could partly explain the increase in thrombotic risk among women using such antiestrogenic progestogens. 
All together, results from both ESTHER and E3N studies suggest that the safest option for correcting menopausal women may be transdermal estrogens combined with micronized progesterone. However, randomized controlled trials are needed to confirm this result.

\section{Tibolone}

Tibolone, a testosterone derived progestin, has estrogenic, progestogenic and androgenic properties [24]. Tibolone can be used alone as treatment of climacteric symptoms among postmenopausal women [25, 26]. It is administrated at low dose and its effect is partly mediated by its metabolites. The association of VTE with tibolone use among postmenopausal women has been so far only investigated in one case/control study [16], one cohort study [8] and two randomized controlled trials [25, 26]. All the studies showed that tibolone use was not associated with the risk of VTE. Using a random-effect model meta-analysis as previously described [4, 9], the overall VTE risk was $0.5(95 \% \mathrm{Cl}: 0.1-2.0)$ among postmenopausal women using tibolone as compared to non users or placebo users (figure 2). However, the wide confidence interval did not allow concluding regarding the impact of tibolone on VTE risk and we cannot exclude an increase in the VTE risk of $100 \%$ among users of tibolone. Further data are therefore needed to clarify the effect of tibolone on VTE risk, especially among healthy postmenopausal women. 


\section{Progestogens and haemostatis: biological studies}

For many years, the effect of HT on haemostatis has been largely investigated in observational studies as well as in high evidence level studies among users of oral and transdermal estrogens [27-52]. However, few studies, which most of them were randomized controlled trials, were adequately designed for assessing the effect of progestogens or for comparing the effect of a specific progestogen to each other on APCr, a validated surrogate marker of VTE and on F1+2 or Ddimers, first-generation biomarkers of coagulation and fibrinolysis [29, 33, 40, 41, 43, 47-51, 53] (table 2). In addition, because postmenopausal women using progestogens are also prescribed estrogens, it is important to note that the influence of progestogens on haemostasis among postmenopausal women has been only investigated in a context of estrogens use.

On one hand, some data allowed assessing the main effect of some progestogens by comparing the changes in haemostasis between users of oral estrogens alone or combined with either micronized progesterone [51], dydrogesterone [33, 40], MPA [29, 47, 51], trimegestone [33, 40] or gestodene [43]. Micronized progesterone, dydrogesterone, MPA and trimegestone may not induce significant changes in $\mathrm{F} 1+2$, DDimers and APCr related to oral estrogens use. As part of the investigation regarding MPA, these biological data are not in accordance with the clinical results which show an increased VTE risk among users of CEE+MPA as compared with CEE alone users. However, since oral estrogens activate blood coagulation and induce APCr, a potential influence of progestogen on haemostasis could be diluted by oral estrogens effect and partly explain why little or no variation was detected. With regard to gestodene, data remained inconclusive with a higher increase in DDimers but a lower one in APCr among gestodene users [43].

On the other hand, some studies compared the effect of two different progestogens on haemostasis in the context of either oral estrogen users [29, 33, 40, 48, 49, 51, 54] or transdermal estrogens users [53]. Among oral estrogens users, no clear differences have been highlighted. While a randomized controlled trials showed no significant difference in blood coagulation activation and APCr between trimegestone and dydrogesterone [33, 40], another study showed that trimegestone was associated with a significantly higher increase in DDimers concentration as compared 
to dydrogesterone [49]. When compared to other progestogen, MPA could have similar [51] or more deleterious effect [41,50] on haemostasis, suggesting a potential detrimental impact of progestogens with androgenic properties on coagulation. Because transdermal estrogens, contrary to oral estrogens, have little or no effect on blood coagulation activation [43], studying the impact of progestogens on haemostasis seems to be more relevant among postmenopausal women using transdermal ET. The Study of NorpregnAnes of Coagulation (SNAC) provided the only data comparing the impact of micronised progesterone and norpregnane derivatives on haemostasis among transdermal estrogens users [53]. In the study, norpregnane derivatives, but not micronized progesterone, were associated with an increase in $\mathrm{F} 1+2$ concentrations and an $\mathrm{APCr}$ induction. These results were concordant with clinical data showing an association between norpregnane derivatives but not micronized progesterone with the VTE risk. However, the SNAC study was a cross-sectional study and a selection bias might have occurred, as described in the clinical data.

In conclusion, no clear evidence for a differential effect of progestogens on haemostasis has been highlighted but norpregnane derivatives could activate blood coagulation and induce APCr [53], providing a biological support to the clinical results $[6,7]$.

\section{Tibolone}

Data regarding the effect of tibolone on haemostasis are scarce [55-62]. Only one study provided a direct assessment of the tibolone effect on F1+2, DDimers and APCr and showed that compared to placebo treatment, tibolone would not significantly induce a higher APCr [62] (table 3). However, this study included a low number of subjects and the lach of statistical power did not allow clearly concluding. Two studies consistently showed that tibolone would have the same or a less deleterious effect on F1+2 and DDimers than did CEE or E2 combined with NETA [55, 56, 59-61]. By contrast, data were more controversial regarding the comparison of the effects of tibolone and estrogens combined with NETA on APCr. While tibolone might more induced $\mathrm{APCr}$ than did estradiol and estriol, it could have less effect on haemostasis than did CEE [55, 59-61]. With regards to other progestogens, one study has investigated the differential effect of tibolone and CEE combined with micronized progesterone on haemostasis and showed that increase in F1+2 was 
more pronounced among HT users compared to tibolone ones [57]. Overall, data on the effect of tibolone on haemostasis remain conflicting and further investigations are needed to clarify this effect. 


\section{Conclusion}

In conclusion, progestogens, as part of a HT compound for postmenopausal women, may have differential effects on VTE risk according to the molecules and therefore recently emerge as an important determinant of the thrombotic risk. While MPA has a thrombogenic effect among postmenopausal women using estrogens, micronized progesterone could be safe with respect to thrombotic risk. However, the effects of the different types of progestogens on VTE risk has to be further investigated in high evidence level studies performed among postmenopausal women using estrogens. 


\section{References}

1. Role of progestogen in hormone therapy for postmenopausal women: position statement of The North American Menopause Society. Menopause 2003, 10:113-132.

2. Rossouw JE, Anderson GL, Prentice RL, LaCroix AZ, Kooperberg C, Stefanick ML, Jackson RD, Beresford SA, Howard BV, Johnson KC, et al: Risks and benefits of estrogen plus progestin in healthy postmenopausal women: principal results From the Women's Health Initiative randomized controlled trial. Jama 2002, 288:321-333.

3. Anderson GL, Limacher M, Assaf AR, Bassford T, Beresford SA, Black H, Bonds D, Brunner R, Brzyski R, Caan B, et al: Effects of conjugated equine estrogen in postmenopausal women with hysterectomy: the Women's Health Initiative randomized controlled trial. Jama 2004, 291:1701-1712.

4. Olie V, Canonico M, Scarabin PY: Risk of venous thrombosis with oral versus transdermal estrogen therapy among postmenopausal women. Curr Opin Hematol 2010, 17:457-463.

5. Scarabin PY, Oger E, Plu-Bureau G: Differential association of oral and transdermal oestrogen-replacement therapy with venous thromboembolism risk. Lancet 2003, 362:428-432.

6. Canonico M, Oger E, Plu-Bureau G, Conard J, Meyer G, Levesque H, Trillot N, Barrellier MT, Wahl D, Emmerich J, Scarabin PY: Hormone therapy and venous thromboembolism among postmenopausal women: impact of the route of estrogen administration and progestogens: the ESTHER study. Circulation 2007, 115:840-845.

7. Canonico M, Fournier A, Carcaillon L, Olie V, Plu-Bureau G, Oger E, Mesrine S, Boutron-Ruault MC, Clavel-Chapelon F, Scarabin PY: Postmenopausal hormone therapy and risk of idiopathic venous thromboembolism: results from the E3N cohort study. Arterioscler Thromb Vasc Biol 2010, 30:340-345.

8. Renoux C, Dell'Aniello S, Suissa S: Hormone replacement therapy and the risk of venous thromboembolism: a population-based study. J Thromb Haemost 2010, 8:979-986.

9. Canonico M, Plu-Bureau G, Lowe GD, Scarabin PY: Hormone replacement therapy and risk of venous thromboembolism in postmenopausal women: systematic review and meta-analysis. Bmj 2008, 336:1227-1231.

10. Curb JD, Prentice RL, Bray PF, Langer RD, Van Horn L, Barnabei VM, Bloch MJ, Cyr MG, Gass M, Lepine L, et al: Venous thrombosis and conjugated equine estrogen in women without a uterus. Arch Intern Med 2006, 166:772780.

11. Vickers MR, MacLennan AH, Lawton B, Ford D, Martin J, Meredith SK, DeStavola BL, Rose S, Dowell A, Wilkes HC, et al: Main morbidities recorded in the women's international study of long duration oestrogen after menopause (WISDOM): a randomised controlled trial of hormone replacement therapy in postmenopausal women. Bmj 2007, 335:239.

12. Allen NE, Tsilidis KK, Key TJ, Dossus L, Kaaks R, Lund E, Bakken K, Gavrilyuk O, Overvad K, Tjonneland A, et al: Menopausal hormone therapy and risk of endometrial carcinoma among postmenopausal women in the European Prospective Investigation Into Cancer and Nutrition. Am J Epidemiol 2010, 172:1394-1403. 
13. Sitruk-Ware R: Pharmacological profile of progestins. Maturitas 2004, 47:277283.

14. Nath A, Sitruk-Ware R: Different cardiovascular effects of progestins according to structure and activity. Climacteric 2009, 12 Suppl 1:96-101.

15. Sitruk-Ware R: New progestogens: a review of their effects in perimenopausal and postmenopausal women. Drugs Aging 2004, 21:865-883.

16. Daly E, Vessey MP, Hawkins MM, Carson JL, Gough P, Marsh S: Risk of venous thromboembolism in users of hormone replacement therapy. Lancet 1996, 348:977-980.

17. Jick H, Derby LE, Myers MW, Vasilakis C, Newton KM: Risk of hospital admission for idiopathic venous thromboembolism among users of postmenopausal oestrogens. Lancet 1996, 348:981-983.

18. Perez Gutthann S, Garcia Rodriguez LA, Castellsague J, Duque Oliart A: Hormone replacement therapy and risk of venous thromboembolism: population based case-control study. Bmj 1997, 314:796-800.

19. Smith NL, Heckbert SR, Lemaitre RN, Reiner AP, Lumley T, Weiss NS, Larson EB, Rosendaal FR, Psaty BM: Esterified estrogens and conjugated equine estrogens and the risk of venous thrombosis. Jama 2004, 292:15811587.

20. Cushman M, Kuller LH, Prentice R, Rodabough RJ, Psaty BM, Stafford RS, Sidney S, Rosendaal FR: Estrogen plus progestin and risk of venous thrombosis. Jama 2004, 292:1573-1580.

21. Fraser DI, Padwick ML, Whitehead MI, White J, Ryder TA, Pryse-Davies J: The effects of the addition of nomegestrol acetate to post-menopausal oestrogen therapy. Maturitas 1989, 11:21-34.

22. Sitruk-Ware R: Progestogens in hormonal replacement therapy: new molecules, risks, and benefits. Menopause 2002, 9:6-15.

23. Simon T, Beau Yon de Jonage-Canonico M, Oger E, Wahl D, Conard J, Meyer G, Emmerich J, Barrellier MT, Guiraud A, Scarabin PY: Indicators of lifetime endogenous estrogen exposure and risk of venous thromboembolism. $J$ Thromb Haemost 2006, 4:71-76.

24. de Gooyer ME, Deckers GH, Schoonen WG, Verheul HA, Kloosterboer HJ: Receptor profiling and endocrine interactions of tibolone. Steroids 2003, 68:21-30.

25. Cummings SR, Ettinger B, Delmas PD, Kenemans $P$, Stathopoulos V, Verweij P, Mol-Arts M, Kloosterboer L, Mosca L, Christiansen C, et al: The effects of tibolone in older postmenopausal women. N Engl J Med 2008, 359:697-708.

26. Kenemans P, Bundred NJ, Foidart JM, Kubista E, von Schoultz B, Sismondi P, Vassilopoulou-Sellin R, Yip CH, Egberts J, Mol-Arts M, et al: Safety and efficacy of tibolone in breast-cancer patients with vasomotor symptoms: a double-blind, randomised, non-inferiority trial. Lancet Oncol 2009, 10:135-146.

27. Conard J, Basdevant A, Thomas JL, Ochsenbein E, Denis C, Guyene TT, Degrelle $\mathrm{H}$ : Cardiovascular risk factors and combined estrogen-progestin replacement therapy: a placebo-controlled study with nomegestrol acetate and estradiol. Fertil Steril 1995, 64:957-962.

28. Egarter C, Geurts P, Boschitsch E, Speiser P, Huber J: The effects of estradiol valerate plus medroxyprogesterone acetate and conjugated estrogens plus medrogestone on climacteric symptoms and metabolic variables in perimenopausal women. Acta Obstet Gynecol Scand 1996, 75:386-393. 
29. Koh KK, Mincemoyer R, Bui MN, Csako G, Pucino F, Guetta V, Waclawiw M, Cannon RO, 3rd: Effects of hormone-replacement therapy on fibrinolysis in postmenopausal women. N Engl J Med 1997, 336:683-690.

30. Scarabin PY, Alhenc-Gelas M, Plu-Bureau G, Taisne P, Agher R, Aiach M: Effects of oral and transdermal estrogen/progesterone regimens on blood coagulation and fibrinolysis in postmenopausal women. A randomized controlled trial. Arterioscler Thromb Vasc Biol 1997, 17:3071-3078.

31. Hoibraaten E, Os I, Seljeflot I, Andersen TO, Hofstad A, Sandset PM: The effects of hormone replacement therapy on hemostatic variables in women with angiographically verified coronary artery disease: results from the estrogen in women with atherosclerosis study. Thromb Res 2000, 98:19-27.

32. Teede HJ, McGrath BP, Smolich JJ, Malan E, Kotsopoulos D, Liang YL, Peverill RE: Postmenopausal hormone replacement therapy increases coagulation activity and fibrinolysis. Arterioscler Thromb Vasc Biol 2000, 20:1404-1409.

33. van Baal WM, Emeis JJ, van der Mooren MJ, Kessel H, Kenemans P, Stehouwer CD: Impaired procoagulant-anticoagulant balance during hormone replacement therapy? A randomised, placebo-controlled 12-week study. Thromb Haemost 2000, 83:29-34.

34. Chen FP, Lee N, Soong YK, Huang KE: Short- and long-term effects of hormone replacement therapy on cardiovascular risk factors in postmenopausal women. Chang Gung Med J 2001, 24:431-439.

35. Demirol A, Baykal C, Kirazli S, Ayhan A: Effects of hormone replacement on hemostasis in spontaneous menopause. Menopause 2001, 8:135-140.

36. Gottsater A, Rendell M, Hulthen UL, Berntorp E, Mattiasson I: Hormone replacement therapy in healthy postmenopausal women: a randomized, placebo-controlled study of effects on coagulation and fibrinolytic factors. $J$ Intern Med 2001, 249:237-246.

37. Hoibraaten E, Mowinckel MC, de Ronde H, Bertina RM, Sandset PM: Hormone replacement therapy and acquired resistance to activated protein $\mathrm{C}$ : results of a randomized, double-blind, placebo-controlled trial. $\mathrm{Br} \mathrm{J}$ Haematol 2001, 115:415-420.

38. Lobo RA, Bush T, Carr BR, Pickar JH: Effects of lower doses of conjugated equine estrogens and medroxyprogesterone acetate on plasma lipids and lipoproteins, coagulation factors, and carbohydrate metabolism. Fertil Steril 2001, 76:13-24.

39. Perera M, Sattar N, Petrie JR, Hillier C, Small M, Connell JM, Lowe GD, Lumsden MA: The effects of transdermal estradiol in combination with oral norethisterone on lipoproteins, coagulation, and endothelial markers in postmenopausal women with type 2 diabetes: a randomized, placebocontrolled study. J Clin Endocrinol Metab 2001, 86:1140-1143.

40. Post MS, Rosing J, Van Der Mooren MJ, Zweegman S, Van Baal WM, Kenemans P, Stehouwer CD: Increased resistance to activated protein C after short-term oral hormone replacement therapy in healthy post-menopausal women. Br J Haematol 2002, 119:1017-1023.

41. Skouby SO, Gram J, Andersen LF, Sidelmann J, Petersen KR, Jespersen J: Hormone replacement therapy: estrogen and progestin effects on plasma Creactive protein concentrations. Am J Obstet Gynecol 2002, 186:969-977.

42. Oger E, Alhenc-Gelas M, Lacut K, Blouch MT, Roudaut N, Kerlan V, Collet M, Abgrall JF, Aiach M, Scarabin PY, Mottier D: Differential effects of oral and 
transdermal estrogen/progesterone regimens on sensitivity to activated protein $\mathrm{C}$ among postmenopausal women: a randomized trial. Arterioscler Thromb Vasc Biol 2003, 23:1671-1676.

43. Post MS, Christella M, Thomassen LG, van der Mooren MJ, van Baal WM, Rosing J, Kenemans P, Stehouwer CD: Effect of oral and transdermal estrogen replacement therapy on hemostatic variables associated with venous thrombosis: a randomized, placebo-controlled study in postmenopausal women. Arterioscler Thromb Vasc Biol 2003, 23:1116-1121.

44. Stevenson JC, Oladipo A, Manassiev N, Whitehead MI, Guilford S, Proudler AJ: Randomized trial of effect of transdermal continuous combined hormone replacement therapy on cardiovascular risk markers. Br J Haematol 2004, 124:802-808.

45. Collins P, Flather M, Lees B, Mister R, Proudler AJ, Stevenson JC: Randomized trial of effects of continuous combined HRT on markers of lipids and coagulation in women with acute coronary syndromes: WHISP Pilot Study. Eur Heart J 2006, 27:2046-2053.

46. Taner MZ, Ozpolat E, Taskiran C, Onan MA, Gursel T, Karabulut E, Gursoy R, Himmetoglu O: Effects of four different regimens of hormone replacement therapy on hemostatic parameters: a prospective randomized study. Maturitas 2006, 53:267-273.

47. Bonduki CE, Lourenco DM, Motta EL, Soares Jr JM, Haidar MA, Baracat EC: Effect of estrogen-progestin hormonal replacement therapy on blood coagulation and fibrinolysis in postmenopausal women. Clinics (Sao Paulo) 2007, 62:553-560.

48. Endrikat J, Sandri M, Gerlinger C, Rubig A, Schmidt W, Fortier M: A Canadian multicentre prospective study on the effects of an oral contraceptive containing $3 \mathrm{mg}$ drospirenone and 30 microg ethinyl oestradiol on somatic and psychological symptoms related to water retention and on body weight. Eur $J$ Contracept Reprod Health Care 2007, 12:220-228.

49. Norris LA, Brosnan J, Bonnar J, Conard J, Kluft C, Hellgren M: Inhibitors and activation markers of the haemostatic system during hormone therapy: a comparative study of oral estradiol $(2 \mathrm{mg}) /$ dydrogesterone and estradiol (2 $\mathrm{mg}$ )/ trimegestone. Thromb Haemost 2008, 100:253-260.

50. Skouby SO, Sidelmann JJ, Nilas L, Gram J, Jespersen J: The effect of continuous combined conjugated equine estrogen plus medroxyprogesterone acetate and tibolone on cardiovascular metabolic risk factors. Climacteric 2008, 11:489-497.

51. Smith NL, Wiley JR, Legault C, Rice KM, Heckbert SR, Psaty BM, Tracy RP, Cushman M: Effect of progestogen and progestogen type on hemostasis measures in postmenopausal women: the Postmenopausal Estrogen/Progestin Intervention (PEPI) Study. Menopause 2008, 15:11451150.

52. Samsioe G, Hruska J: Optimal tolerability of ultra-low-dose continuous combined 17beta-estradiol and norethisterone acetate: laboratory and safety results. Climacteric 2010, 13:34-44.

53. Canonico M, Alhenc-Gelas M, Plu-Bureau G, Olie V, Scarabin PY: Activated protein $\mathrm{C}$ resistance among postmenopausal women using transdermal estrogens: importance of progestogen. Menopause 2010, 17:1122-1127. 
54. Sidelmann JJ, Jespersen J, Andersen LF, Skouby SO: Hormone replacement therapy and hypercoagulability. Results from the Prospective Collaborative Danish Climacteric Study. Bjog 2003, 110:541-547.

55. Winkler UH, Altkemper R, Kwee B, Helmond FA, Coelingh Bennink HJ: Effects of tibolone and continuous combined hormone replacement therapy on parameters in the clotting cascade: a multicenter, double-blind, randomized study. Fertil Steril 2000, 74:10-19.

56. Norris LA, Joyce M, O'Keeffe N, Sheppard BL, Bonnar J: Haemostatic risk factors in healthy postmenopausal women taking hormone replacement therapy. Maturitas 2002, 43:125-133.

57. Koh KK, Ahn JY, Jin DK, Yoon BK, Kim HS, Kim DS, Kang WC, Han SH, Choi IS, Shin EK: Significant differential effects of hormone therapy or tibolone on markers of cardiovascular disease in postmenopausal women: a randomized, double-blind, placebo-controlled, crossover study. Arterioscler Thromb Vasc Biol 2003, 23:1889-1894.

58. Koh KK, Han SH, Shin MS, Ahn JY, Lee Y, Shin EK: Significant differential effects of lower doses of hormone therapy or tibolone on markers of cardiovascular disease in post-menopausal women: a randomized, doubleblind, crossover study. Eur Heart J 2005, 26:1362-1368.

59. Eilertsen AL, Qvigstad E, Andersen TO, Sandvik L, Sandset PM: Conventional-dose hormone therapy $(\mathrm{HT})$ and tibolone, but not low-dose HT and raloxifene, increase markers of activated coagulation. Maturitas 2006, 55:278-287.

60. Eilertsen AL, Liestol S, Mowinckel MC, Hemker HC, Sandset PM: Differential impact of conventional and low-dose oral hormone therapy (HT), tibolone and raloxifene on functionality of the activated protein $\mathrm{C}$ system. Thromb Haemost 2007, 97:938-943.

61. Eilertsen AL, Sandvik L, Mowinckel MC, Andersen TO, Qvigstad E, Sandset PM: Differential effects of conventional and low dose oral hormone therapy $(\mathrm{HT})$, tibolone, and raloxifene on coagulation and fibrinolysis. Thromb Res 2007, 120:371-379.

62. Demirol A, Guven S, Guvendag Guven ES, Kirazli S, Gurgan T, Ayhan A: Comparison of the effects of tibolone and estrogen therapy on hemostasis in surgical menopause: a randomized, double-blind, placebo-controlled study. Fertil Steril 2007, 87:842-848. 
Table 1. Hormonal effect of the different progestogens used among postmenopausal women

\begin{tabular}{|c|c|c|c|c|c|c|c|}
\hline Pharmacological class & Molecules & $\begin{array}{l}\text { Progestogenic } \\
\text { activity }\end{array}$ & $\begin{array}{l}\text { Estrogenic } \\
\text { activity }\end{array}$ & $\begin{array}{l}\text { Androgenic } \\
\text { activity }\end{array}$ & $\begin{array}{l}\text { Anti-androgenic } \\
\text { activity }\end{array}$ & $\begin{array}{l}\text { Gluco-corticoid } \\
\text { activity }\end{array}$ & $\begin{array}{l}\text { Anti Mineralo- } \\
\text { corticoid }\end{array}$ \\
\hline Micronised progesterone & Micronised progesterone & + & - & - & $+/-$ & $+/-$ & + \\
\hline \multirow[t]{4}{*}{ Pregnanes } & Dydrogesterone & + & - & - & - & - & - \\
\hline & Medrogestone & + & - & - & - & - & - \\
\hline & Cyproterone acetate & ++ & - & - & +++ & + & - \\
\hline & $\begin{array}{l}\text { Medroxyprogesterone } \\
\text { acetate }\end{array}$ & + & - & + & - & + & - \\
\hline \multirow[t]{3}{*}{ Norpregnanes } & Nomegestrol acetate & + & - & - & + & - & - \\
\hline & Promegestone & + & - & - & - & + & - \\
\hline & Trimegestone & + & - & - & $+/-$ & - & - \\
\hline \multicolumn{8}{|l|}{19 Nortestosterone ethinylated } \\
\hline Estranes & Norethisterone acetate & ++ & + & + & - & - & - \\
\hline \multirow[t]{2}{*}{ Gonanes } & Levonorgestrel & ++ & - & + & - & $+/-$ & - \\
\hline & Gestodene & ++ & - & + & - & $+/-$ & - \\
\hline 19 Nortestosterone non ethinylated & Dienogest & ++ & - & - & + & - & - \\
\hline Spironolactone derivatives & Drospirenone & + & - & - & + & - & ++ \\
\hline Tibolone & Tibolone & + & + & ++ & - & - & - \\
\hline
\end{tabular}


Figure 1: Risk of venous thromboembolism among users of oral estrogens alone or oral estrogens combined with progestogens in observational studies

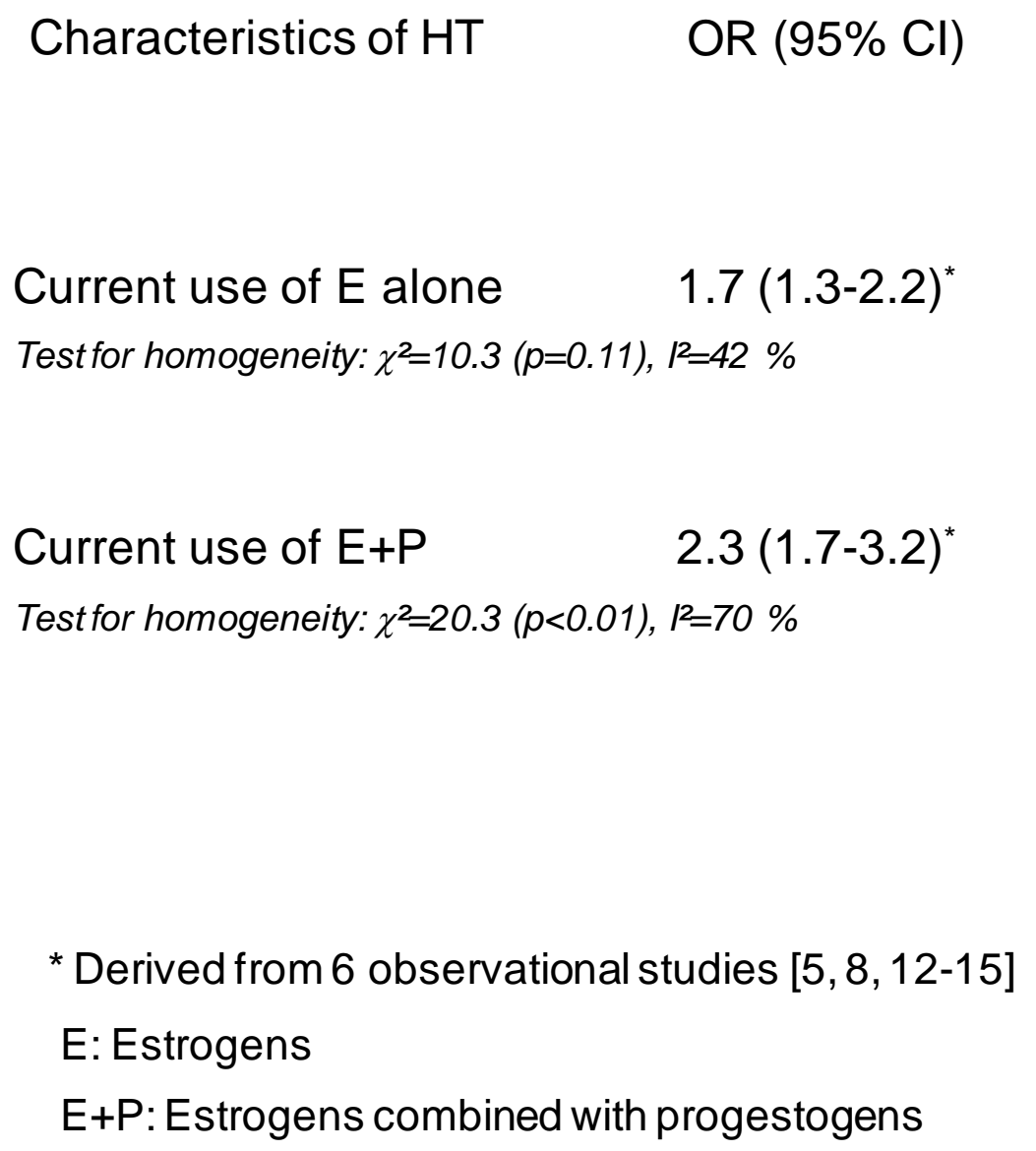

* Derived from 6 observational studies $[5,8,12-15]$

E: Estrogens

$E+P:$ Estrogens combined with progestogens

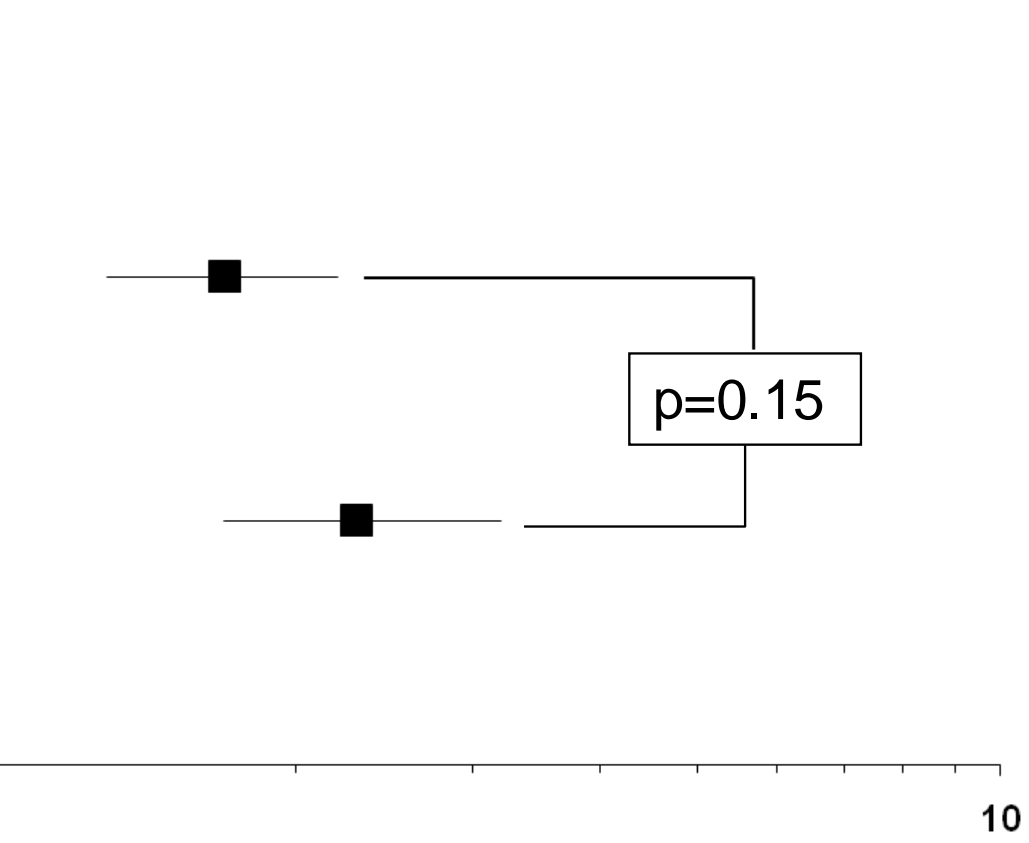


Figure 2: Risk of venous thromboembolism among postmenopausal women using tibolone

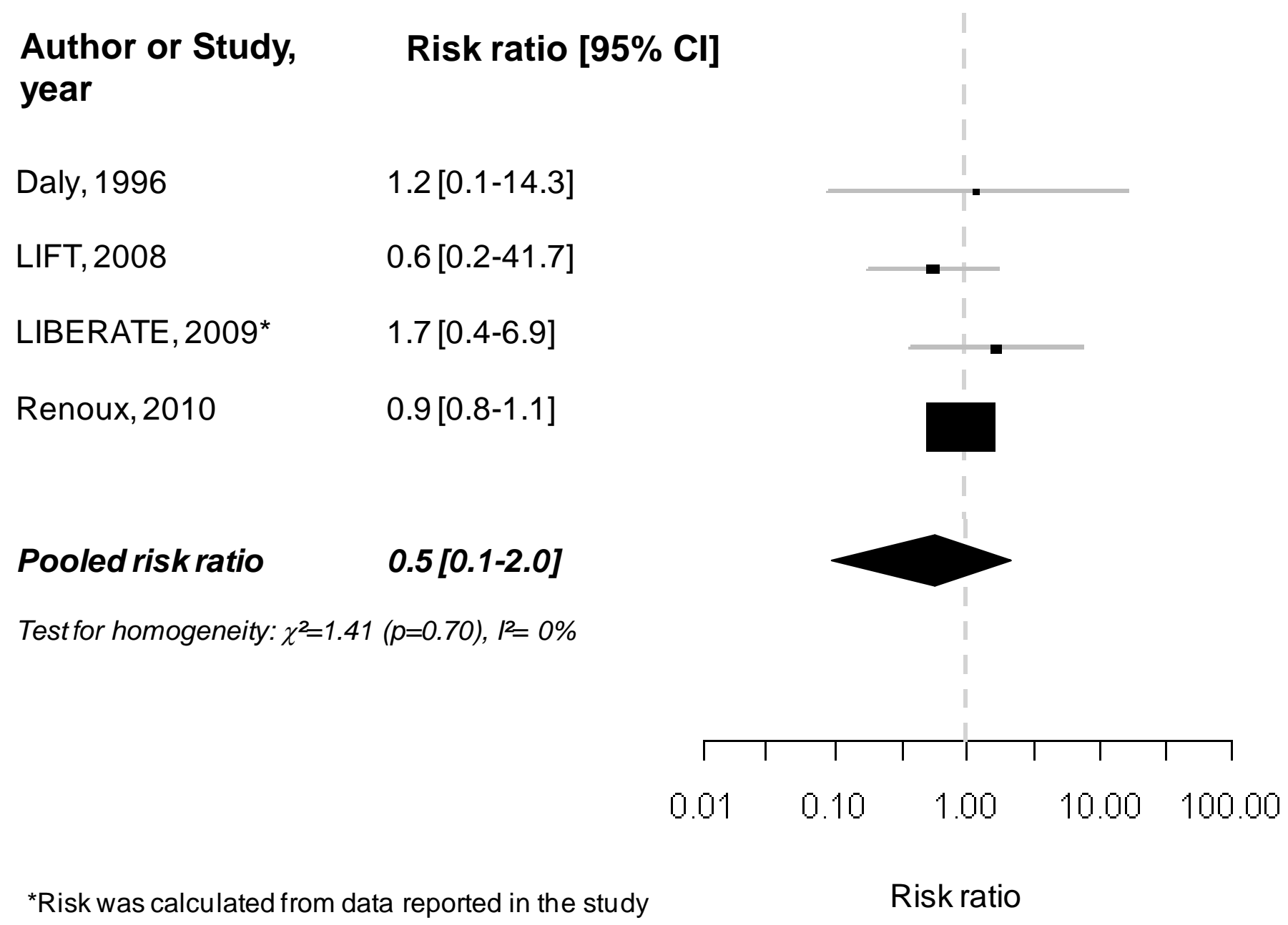


Table 2. Impact of progestogens on haemostasis among postmenopausal women from randomized controlled trials

\begin{tabular}{|c|c|c|c|c|c|c|c|}
\hline \multirow{2}{*}{$\begin{array}{l}\text { Authors, years } \\
\text { of publication }\end{array}$} & \multirow{2}{*}{$\begin{array}{l}\text { Number } \\
\text { of women }\end{array}$} & \multirow[b]{2}{*}{ Groups of treatment } & \multicolumn{2}{|c|}{ Assessed effect } & \multicolumn{3}{|c|}{ Haemostasis } \\
\hline & & & Progestogens & $\begin{array}{l}\text { Route of estrogen } \\
\text { administration }\end{array}$ & $\mathrm{F} 1+2$ & Ddimers & $\mathrm{APCr}$ \\
\hline \multirow{2}{*}{$\begin{array}{l}\text { Koh et al, } \\
1997\end{array}$} & \multirow{2}{*}{50} & $\begin{array}{l}\text { O CEE alone } \\
\text { O CEE + MPA }\end{array}$ & MPA & Oral & NA & NS & NA \\
\hline & & $\begin{array}{l}\text { T E2 alone } \\
\text { T E2 + MPA } \\
\end{array}$ & MPA & Transdermal & NA & NA & NA \\
\hline \multirow{3}{*}{$\begin{array}{l}\text { Van Baal et al, } \\
2000 \text { and Post } \\
\text { et al, } 2002\end{array}$} & \multirow{3}{*}{60} & O E2 alone & Trimegestone & \multirow{2}{*}{ Oral } & NS & NS & NS \\
\hline & & O E2 + Dydrogesterone & $\begin{array}{l}\text { Trimegestone versus } \\
\text { Dydrogesterone }\end{array}$ & & NS & NS & NS \\
\hline & & Placebo & & & & & \\
\hline \multirow{4}{*}{$\begin{array}{l}\text { Skouby et al, } \\
2002\end{array}$} & \multirow{4}{*}{149} & $\mathrm{O} \mathrm{E} 2 \mathrm{cycl}+\mathrm{CPA}$ & \multirow{2}{*}{ CPA versus NOR } & \multirow{4}{*}{ Oral } & \multirow{2}{*}{ NS } & \multirow{2}{*}{ NS } & \multirow{2}{*}{ NS } \\
\hline & & $\mathrm{O}$ E2 cont + CPA & & & & & \\
\hline & & $\begin{array}{l}\mathrm{O} \text { E2 cont + NETA } \\
\mathrm{O} \text { E2 + MPA }\end{array}$ & CPA versus MPA & & $\nearrow$ in MPA & NS & NS \\
\hline & & No Treatment & MPA versus NETA & & 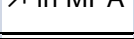 & ש & STu \\
\hline Post et al, & $15 ?$ & $\begin{array}{l}\text { O E2 alone } \\
\text { O E2 + Gestodene }\end{array}$ & Gestodene & Oral & NS & $\begin{array}{l}\nearrow \text { superior with } \\
\text { Gestodene }\end{array}$ & $\begin{array}{l}\pi \text { inferior with } \\
\text { Gestodene } \\
\end{array}$ \\
\hline 2003 & 152 & T E2 alone & & & & & \\
\hline & & Placebo & & & & & \\
\hline Bonduki et al, & 45 & $\begin{array}{l}\text { O CEE alone } \\
\text { O CEE + MPA }\end{array}$ & MPA & Oral & NS & NA & NS \\
\hline & & TE2 + MPA & & & & & \\
\hline Endrikat et al, & 315 & O E2 + Dienogest & Dienogest versus & Oral & NS & NS & \\
\hline 2008 & 315 & $\mathrm{O} E 2$ + NETA & NETA & & & & \\
\hline & & O CEE alone & MP & & NS & NS & NS \\
\hline Smith et al, & & $\mathrm{O}$ CEE + MP & & & & & \\
\hline 2008 & 288 & $\begin{array}{l}\text { O CEE + MPA Cycl } \\
\text { O CEE + MPA cont }\end{array}$ & MPA & Oral & NS & NS & NS \\
\hline & & Placebo & MP versus MPA & & NS & NS & NS \\
\hline 2008 & 100 & $\mathrm{O}$ E2 + Dydrogesterone & dydrogesterone & Tal & INS & Trimegestone & No \\
\hline
\end{tabular}

RCT: Randomised Controlled Trial

NA: Not Applicable; NS: Not Significant difference in haemostatic parameters changes between progestins

O: Oral; T: Transdermal

CEE: Conjugated Equin Estrogens; E2: Estradiol

MP: Micronised Progesterone; MPA: MedroxyProgesterone Acetate; CPA: CyProterone Acetate; LVN: LeVoNorgestrel; NETA: NorEthisTerone Acetate

Cont: continu; Cycl: Cyclic

IUD: Intra Uterin Device 
Table 3. Impact of tibolone on haemostasis among postmenopausal women

\begin{tabular}{|c|c|c|c|c|c|c|c|}
\hline \multirow{2}{*}{$\begin{array}{l}\text { Authors, years } \\
\text { of publication }\end{array}$} & \multirow{2}{*}{$\begin{array}{l}\text { Study } \\
\text { design }\end{array}$} & \multirow{2}{*}{$\begin{array}{l}\text { Number } \\
\text { of women }\end{array}$} & \multirow{2}{*}{ Groups of treatment } & \multirow{2}{*}{ Assessed effect } & \multicolumn{3}{|c|}{ Haemostasis } \\
\hline & & & & & $\mathrm{F} 1+2$ & Ddimers & $\mathrm{APCr}$ \\
\hline $\begin{array}{l}\text { Winkler et al, } \\
2000\end{array}$ & RT & 60 & $\begin{array}{l}\text { Tibolone } \\
\mathrm{OE} 2 \text { + O E3 + NETA } \\
\end{array}$ & $\begin{array}{l}\text { Tibolone versus O E2 + } \\
\text { E3 + NETA }\end{array}$ & $\begin{array}{l}\text { 7 superior } \\
\text { with } \mathrm{HT}\end{array}$ & $\begin{array}{l}\text { オ superior with } \\
\text { HT }\end{array}$ & $\begin{array}{l}\text { T superior } \\
\text { with Tibolone } \\
\end{array}$ \\
\hline $\begin{array}{l}\text { Norris et al, } \\
2002\end{array}$ & RT & 80 & $\begin{array}{l}\mathrm{OE} 2+\mathrm{NETA} \\
\text { Tibolone } \\
\end{array}$ & $\begin{array}{l}\text { Tibolone versus O E2 + } \\
\text { NETA }\end{array}$ & NA & $\begin{array}{l}\text { त superior with } \\
\text { HT }\end{array}$ & NA \\
\hline $\begin{array}{l}\text { Koh et al, } \\
2003 \text { and } 2005\end{array}$ & RT & 53 & $\begin{array}{l}\text { O CEE + MP } \\
\text { Tibolone } \\
\end{array}$ & $\begin{array}{l}\text { Tibolone versus O CEE } \\
+\mathrm{MP}\end{array}$ & $\begin{array}{l}\text { 7 superior } \\
\text { with Tibolone }\end{array}$ & NA & NA \\
\hline \multirow{3}{*}{$\begin{array}{l}\text { Eilersten et al, } \\
2006 \text { and } 2007\end{array}$} & \multirow{3}{*}{ RT } & \multirow{3}{*}{202} & $\begin{array}{l}\text { Low dose O E2 + NETA } \\
\text { High dose O E2 + NETA }\end{array}$ & $\begin{array}{l}\text { Tibolone versus high } \\
\text { dose of O E2 + NETA }\end{array}$ & $\begin{array}{l}7 \text { superior } \\
\text { with } \mathrm{HT} \\
\end{array}$ & $\begin{array}{l}\text { त superior with } \\
\mathrm{HT}\end{array}$ & $\begin{array}{l}\text { त superior } \\
\text { with } \mathrm{HT}\end{array}$ \\
\hline & & & Tibolone & $\begin{array}{l}\text { Tibolone versus low } \\
\text { dose of O E2 + NETA }\end{array}$ & NS & NS & $\begin{array}{l}7 \text { superior with } \\
\text { HT }\end{array}$ \\
\hline & & & Raloxifene & $\begin{array}{l}\text { Tibolone versus } \\
\text { Raloxifene }\end{array}$ & NS & $\begin{array}{l}7 \text { with Tibolone } \\
\searrow \text { with raloxifene }\end{array}$ & NA \\
\hline \multirow{2}{*}{$\begin{array}{l}\text { Demirol et al, } \\
2007\end{array}$} & \multirow[t]{2}{*}{$\mathrm{RCT}$} & \multirow[t]{2}{*}{90} & $\begin{array}{l}\text { O CEE } \\
\text { Tibolone }\end{array}$ & Tibolone versus O CEE & NA & NA & NS \\
\hline & & & Placebo & Tibolone versus placebo & NA & NA & NS \\
\hline RT: Randomise & Trial; $\mathrm{R}$ & Randomise & d Controlled Trial & & & & \\
\hline NA: Not Applica & ole; NS: I & Significant & difference & & & & \\
\hline O: Oral; & & & & & & & \\
\hline CEE: Conjugate & Equin $\mathrm{E}$ & ogens; E2: & Estradiol; E3: Estriol & & & & \\
\hline MP: Micronised & Progeste & $\mathrm{e} ;$ NETA: 1 & orethisterone Acetate & & & & \\
\hline
\end{tabular}

